\title{
PENERIMAAN GURU DENGAN PELAKSANAAN SISTEM MAKLUMAT MURID DAN APLIKASI PANGKALAN DATA MURID DALAM PENGURUSAN DATA MURID
}

\section{TEACHER ACCEPTANCE OF THE IMPLEMENTATION OF STUDENT INFORMATION SYSTEMS AND STUDENT DATABASE APPLICATIONS IN STUDENT DATA MANAGEMENT}

\author{
Norin Farizah Mohd Nuin ${ }^{1}$ \\ SMJK Shan Tao Kota Kinabalu \\ (Email: farizahnorin@gmail.com) \\ Abdul Said Ambotang 2 \\ Universiti Malaysia Sabah \\ (Email: said@ums.edu.my)
}

Received date: $27-05-2019$

Revised date: $21-07-2019$

Accepted date: 22-07-2019

Published date: 15-09-2019

To cite this document: Nuin, N. F. M., \& Ambotang, A. S. (2019). Penerimaan Guru dengan Pelaksanaan Sistem Maklumat Murid dan Aplikasi Pangkalan Data Murid dalam Pengurusan Data Murid. International Journal of Education, Psychology and Counseling, 4 (32), 180196.

DOI: $10.35631 /$ IJEPC.4320018

Abstrak: Kajian ini dijalankan bertujuan mengenal pasti pelaksanaan Sistem Maklumat Murid (SMM) dan Aplikasi Pangkalan Data Murid (APDM) dalam Pengurusan Data Murid. Semua sekolah menengah kebangsaan di daerah Lahad Datu dijadikan lokasi kajian. Kajian ini melibatkan seramai 181 sampel daripada keseluruhan populasi berjumlah 346 guru kelas. Sampel kajian yang dipilih adalah menggunakan teknik pensampelan rawak mudah. Analisis kajian ini melibatkan statistik deskriptif dan analisis inferens. Data-data diperoleh melalui soal selidik dengan menggunakan Skala Likert. Data-data ini dianalisis dengan menggunakan perisian SPSS versi 21.0 untuk menentukan frekuensi, peratus, min, sisihan piawai, dan pekali Pearson. Dalam kajian ini didapati tidak terdapat perbezaan yang signifikan terhadap penerimaan guru dalam pelaksanaan SMM dan APDM. Kajian ini mendapati bahawa terdapat hubungan yang signifikan di antara SMM dan Pengurusan Data Murid serta APDM dan Pengurusan Data Murid, namun kedua - dua pemboleh ubah tidak bersandar ini tidak mempunyai hubungan yang kuat dengan pemboleh ubah bersandar. Walakin begitu, hasil kajian mendapati terdapat hubungan yang kuat di antara SMM dan APDM kerana kedua-dua sistem ini mempunyai fungsi yang sama.

Kata Kunci: Sistem Maklumat Murid, Aplikasi Pangkalan Data dan Pengurusan Data Murid 
Abstract: This study was carried out to identify the implementation of the Student Information System (SIS) and Pupil Database Applications (PDA) in Student Data Management. All secondary schools in the Lahad Datu District turned into a study. The study involved a total of 181 samples from the entire population totaling 346 classroom teachers. The study sample was selected using simple random sampling technique. This study involves the analysis descriptive statistics and inferential analysis. The data obtained through the questionnaire using Likert scale. These data were analyzed using SPSS version 21.0 to determine the frequency, percentage, mean, standard deviation, and Pearson. The study found no significant differences to the acceptance of the implementation SMM and APDM. This study found a significant relationship between SMM and Student Data Management, Data Management Students and APDM and yet both - two independent variables do not have a strong relationship with the dependent variable. However, the study found that there is a strong relationship between SMM and APDM because both systems have the same functions.

Keywords: Student Information System, Pupil Database Applications and Student Data Management

\section{Pengenalan}

Dasawarsa ini, kementerian banyak melaksanakan inovasi dalam pendidikan dengan membangunkan sistem berasaskan web yang merupakan salah satu cabang dalam bidang perkomputeran. Teknologi ini semakin meluas penggunaannya dalam masyarakat dunia. Dalam meniti arus kemodenan ini, banyak aplikasi atau sistem yang telah bertukar kepada sistem yang berasaskan web untuk memudahkan capaian maklumat. Ini dapat dilihat dari segi masa capaian yang lebih singkat untuk menghubungkan pengguna dengan sesuatu sistem.

Selaras dengan hasrat tersebut, pengurusan data pendidikan menggunakan aplikasi teknologi maklumat diberi tumpuan utama. Penggunaan teknologi maklumat membolehkan aplikasi sistem maklumat dibangunkan melalui pangkalan data. Ini bagi membolehkan maklumat digunakan sepenuhnya terutamanya untuk meningkatkan kecekapan pengurusan dan pentadbiran. Justeru, dalam institusi pendidikan sendiri, sekolah dikehendaki menggunakan teknologi maklumat untuk menguruskan maklumat supaya sentiasa tersedia pada bila-bila masa diperlukan (Rashid, 1987). Maklumat ini diperlukan oleh Pejabat Pelajaran Daerah (PPD), Jabatan Pelajaran Negeri (JPN) dan Kementerian Pelajaran Malaysia (KPM) untuk membuat perancangan dan keputusan dari semasa ke semasa. Lantas, maklumat di sekolah hendaklah sentiasa kemas kini, tepat, boleh dipercayai, sahih dan boleh dicapai pada bila-bila masa. Kesahihan maklumat pula perlu dipelihara bagi mengelakkan mengambil keputusan yang salah (Azmi, 2004).

Era teknologi maklumat dengan penggunaan teknologi komputer ini sangat sesuai digunakan dalam pengendalian sesebuah organisasi. Contohnya sistem pengurusan yang melibatkan data-data yang banyak bagi mempercepatkan pengurusan serta perekodan maklumat tanpa perlu melakukannya secara manual. Selain itu, dengan menggunakan teknologi komputer, maklumat dapat disimpan dengan selamat dan berkesan yang mana ini akan memudahkan kerja- kerja penyelenggaraan (Robert G. Murdick, 1977).

Sehubungan dengan itu, proses untuk mendapatkan data murid yang lengkap menjadi satu masalah kepada pentadbir untuk membuat sebarang keputusan dan perancangan berkaitan dengan murid di sekolah. Sistem pengurusan maklumat secara insani (manual) yang ada telah memaksa mereka supaya mengambil masa yang agak lama untuk mendapatkan sesuatu 
maklumat atau rekod pelajar. Teknologi komputer adalah sangat sesuai digunakan dalam pengendalian sistem pengurusan data murid bagi mempercepatkan pengurusan serta memudahkan pihak institusi pengajian tinggi mengeluarkan laporan-laporan tanpa perlu melakukannya secara manual. Menurut Mohd Yusri bin Mahadi (1996), dengan menggunakan teknologi pengkomputeran, segala maklumat dapat dicapai dengan mudah dan semua maklumat sulit terjamin kerahsiaannya.

\section{Latar Belakang Kajian}

Pada tahun 2005, satu sistem maklumat murid berkomputer telah diperkenalkan bagi semua sekolah. Sistem ini mengumpulkan semua maklumat mengenai murid dan keluarganya, pencapaian akademik dan aktiviti kokurikulum dalam komputer. Sistem Maklumat Murid (SMM) ialah satu sistem bersifat stand alone dan digunakan secara offline untuk menyimpan data murid sekolah rendah dan semua sekolah menengah di Malaysia. Sistem ini dibangunkan menggunakan Perisian Pangkalan Data (Microsoft Access) sepenuhnya. Perisian Pangkalan Data ini ialah satu sistem pengurusan pangkalan data ( satu perisian komputer) yang mempercepatkan pemprosesan data dalam pangkalan data berkomputer.

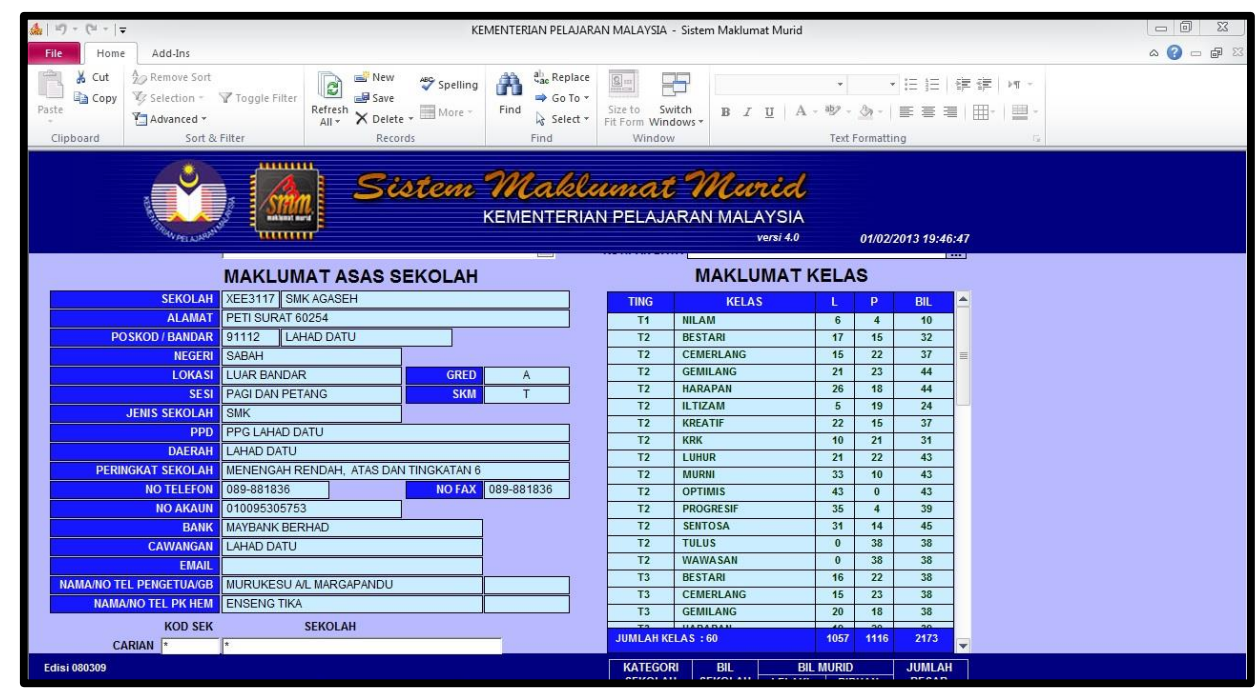

Rajah 1: Sistem Maklumat Murid (SMM)

Semua data murid akan disimpan di dalam Sistem Maklumat Murid (SMM) termasuk maklumat asas murid, maklumat ibu bapa, maklumat kokurikulum murid, bantuan yang diterima oleh murid dan tanggungan ibu bapa murid. Maklumat asas murid adalah terdiri daripada nama, nombor kad pengenalan, nombor surat lahir, kewarganegaraan, kelas, jantina, agama, bangsa, tarikh lahir, tarikh masuk sekolah, alamat, status anak yatim, status Orang Kurang Upaya (OKU), nombor telefon, status asrama dan lain-lain lagi. Manakala dalam maklumat ibu bapa pula terdiri daripada nama, kad pengenalan, agama, bangsa, kewarganegaraan, pekerjaan, bilangan tanggungan, alamat, dan nombor telefon. Dua jenis maklumat di atas biasanya adalah sama daripada maklumat sekolah rendah dan hanya perlu diubah mengikut keperluan. Namun begitu, maklumat kokurikulum, bantuan yang diterima dan tanggungan ibu bapa perlu dikemas kini semasa murid naik ke sekolah menengah.

Dalam pada itu, pada tahun 2012 satu inovasi telah diperkenalkan dalam sistem pangkalan data iaitu Aplikasi Pangkalan Data Murid (APDM) kepada semua sekolah di Malaysia. Sistem ini digunakan secara online sepenuhnya. Fungsi APDM ini ialah menyimpan semua 
data murid dan ia bersifat sharing kerana boleh dikongsi dengan semua guru dan ibu bapa di semua tempat. Selain itu, aplikasi pangkalan data murid ini mempunyai pautan dengan Jabatan Pendaftaran Negara, Sistem Aplikasi Peperiksaan Sekolah (SAPS), Pentaksiran Berasaskan Sekolah (SPPBS) dan Kementerian Pelajaran Malaysia.

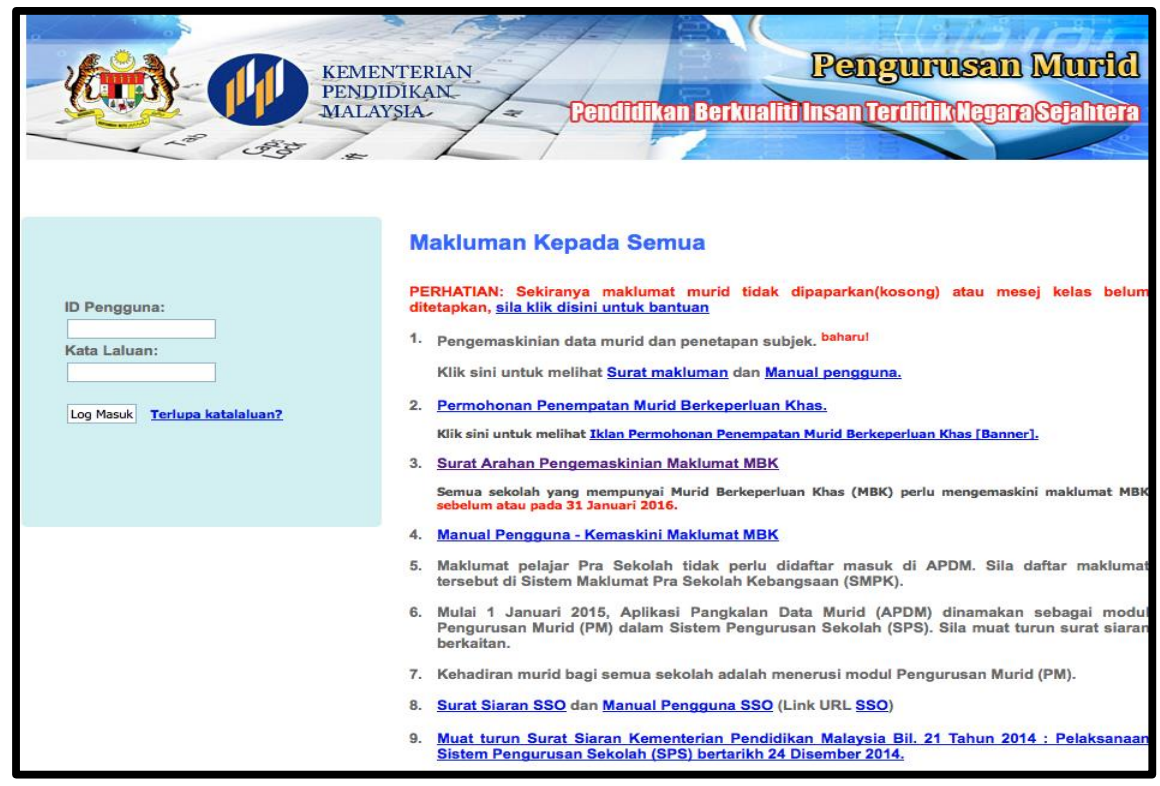

Rajah 2: Aplikasi Pangkalan Data Murid (APDM)

Dalam antara muka (interface) sistem ini terdapat beberapa aplikasi yang disediakan termasuk ePerlu, Tukar kata laluan, Data Murid, Pendaftaran kelas, Pentaksiran, Permohonan (asrama 1 Malaysia dan eDaftar Menengah), Pentadbir sekolah, eDaftar rendah dan Asrama. Pada 15 September 2012, Kerajaan Pelajaran Malaysia (KPM) telah melakukan penambahbaikan terhadap aplikasi ini di mana guru kelas dan ibu bapa boleh membuat permohonan Tingkatan 1 dan Tingkatan 4 bagi sesi persekolahan 2013 ke Sekolah Berasrama Penuh (SBP) serta Sekolah Kawalan, Sekolah Menengah Kebangsaan Agama (SMKA), Kelas Aliran Agama (KAA) dan Kelas Rancangan Khas (KRK) di bawah Jabatan Pelajaran Negeri (JPN).

Selain itu, kementerian telah melakukan satu lagi penambahbaikan dengan membuka sistem pendaftaran Tingkatan 1 bagi tahun 2013 secara atas talian. Pentadbir sekolah/ penyelaras data murid hanya perlu menekan butang daftar dan secara automatik pelajar tersebut telah mendaftar ke sekolah tersebut secara rasmi. Selain itu, bagi murid yang ingin bertukar sekolah, pentadbir sekolah/ penyelaras data murid hanya perlu mendaftar dan membuat rayuan pertukaran ke sekolah yang diingini dan pihak PPD akan menentukan keputusan pertukaran murid tersebut.

Pada tahun 2014, terdapat satu sistem yang diperkenalkan bagi mengganti semua sistemsistem aplikasi sebelum ini iaitu Sistem Pengurusan Sekolah (SPS). Sistem ini mula dilaksanakan di semua sekolah mulai 1 Januari 2015 menerusi Surat Siaran Kementerian Pendidikan Malaysia Bil. 21/2014: Pelaksanaan Sistem Pengurusan Sekolah bertarikh 24 Disember 2014. Dalam sistem ini terbahagi kepada tiga modul iaitu Modul Pengurusan Sekolah, Modul Pengurusan Guru dan Modul Pengurusan Murid. Walau bagaimanapun, APDM tidak digantikan dengan sistem yang baharu ,namun dimasukkan ke dalam Modul 
Pengurusan Murid. Oleh yang demikian APDM tidak dimansuhkan, tetapi hanya ditambah dalam cabang SPS.

Menurut Fullan (2007), implikasi meluas proses pelaksanaan dan penerusan mengandungi beberapa komponen yang berhubung kait iaitu kunci perubahan melibatkan makna yang berkaitan dengan buah fikiran, program, pembaharuan atau kelompok kegiatan yang baharu. Manakala, Pincus (1974) menyatakan bahawa, tiga faktor yang membantu penerimaan iaitu keselamatan birokrasi, reaksi kepada tekanan luar dan penerimaan oleh rakan sebaya elit.

\section{Penyataan Masalah}

Sistem Maklumat Murid (SMM) dan Aplikasi Pangkalan data Murid (APDM) adalah satu sistem yang mempunyai banyak persamaan iaitu melibatkan pengurusan data murid. Perubahan pengurusan sistem yang berlaku menimbulkan banyak persoalan dari segi penerimaan guru. Pelaksanaan perubahan dalam pengurusan data murid melibatkan perubahan pada amalan. Walaupun perubahan boleh berlaku pada pelbagai tahap, namun perubahan pengurusan data murid adalah bukan satu entiti yang mudah kerana ianya melibatkan pelbagai pihak. Fullan (2007) melihat proses perubahan berdasarkan tiga aspek dengan menitikberatkan individu sebagai Jurnal Pendidikan Malaysia 39(1) pelaksana perubahan, iaitu (1) Proses permulaan yang menjurus kepada satu keputusan untuk menerima perubahan; (2) Proses pelaksanaan dengan meletakkan satu konseptual perubahan sebagai satu amalan; dan (3) Proses penginstitusian, iaitu jika perubahan dapat diserapkan dalam sistem dan telah menjadi sebahagian daripada sistem atau sebaliknya, maka perubahan boleh dilaksanakan atau tidak. Menurut Park dan Jeong (2013) pula, perubahan sekolah ialah mengenai proses perubahan individu dan organisasi serta melibatkan proses meningkatkan semangat, afektif, dan faktor-faktor intelektual untuk guru memperbaiki dan memahami amalan pedagogi mereka. apa yang jelas, perubahan dilakukan bertujuan memperbaiki sistem pendidikan di semua peringkat dan kejayaannya mempunyai hubungan yang rapat dengan daya kepimpinan sekolah (Ghitulescu 2013).

Namun begitu, pada bulan Februari tahun 2012 ini, Kementerian Pelajaran Malaysia (KPM) telah melaksanakan inovasi dalam pengurusan data. Pelaksanaan inovasi ini diterajui oleh guru kelas sekali lagi di mana KPM mengarahkan supaya mengisi semula data murid ke dalam Aplikasi Pangkalan Data Murid (APDM) secara online. Menurut Fullan (2006), pelaksanaan dalam satu perubahan melibatkan satu proses pengujian terhadap idea/program/aktiviti/struktur yang perlu dilaksanakan. Justeru, dalam pengujian inovasi ini, guru kelas diminta untuk mengisi data-data murid yang berkaitan seperti data murid, data bapa/penjaga utama dan ibu/penjaga kedua untuk melihat keberkesanan inovasi ini. Fullan juga menyatakan bahawa inovasi berkait dengan isi dalam suatu program baharu, manakala daya membawa inovasi berkaitan dengan keupayaan sesuatu organisasi untuk terlibat dalam penambahbaikan secara berterusan.

Selain itu, terdapat beberapa masalah yang timbul dalam pelaksanaan perubahan ini iaitu penerimaan guru-guru. Tidak semua guru boleh menerima APDM ini kerana mereka telah stabil dengan sistem yang lama iaitu SMM terutamanya guru-guru yang mempunyai pengalaman yang lebih lama. Perbezaan dari segi jantina, umur dan tahap pendidikan. Namun begitu, hal ini boleh diatasi dengan menarik minat mereka dengan mewujudkan sistem yang lebih mudah digunakan dan tidak membebankan. 
Dalam pada itu, satu lagi masalah yang timbul ialah guru kelas dan penyelaras data murid terpaksa mengisi dan mengemas kini data murid di kedua-dua sistem iaitu Sistem Maklumat Murid (SMM) dan Aplikasi Pangkalan Data Murid (APDM) bagi data yang sama. Jika terdapat murid yang baru mendaftar contohnya, guru kelas terpaksa mengisi data murid tersebut di dalam SMM secara offline dan APDM secara online. Untuk pengemaskinian data murid di dalam SMM guru kelas perlu mengambil data asal dari guru penyelaras data murid dan boleh mengemas kini data murid di mana saja dan perlu di export sebelum diserahkan kepada guru penyelaras untuk digabungkan untuk semua kelas.

Kebanyakan sekolah di Sabah masih menggunakan Kad 001 (M) dan sistem yang baharu diperkenalkan ini menambahkan lagi beban kepada tugas guru yang sedia ada. Di samping itu, berlaku pertindihan dalam pengurusan data murid ini kerana guru kelas terpaksa melengkapkan Kad 001 (M), Sistem Maklumat Murid (SMM) dan Aplikasi Pangkalan Data Murid (APDM) untuk data yang sama untuk ketiga-tiga kaedah ini. Namun begitu, merujuk kepada Surat Pekeliling Ikhtisas Kementerian Pendidikan Malaysia Bilangan 1 Tahun 2017 (21 Februari 2017) iaitu arahan Pemansuhan Kad Rekod Persekolahan (Pupil's Cumulative Record Card) untuk sekolah murid sekolah rendah 001R (warna kuning) dan murid sekolah menengah 001M (warna biru ). Ini menunjukkan pengurusan data murid sedang mengalami perubahan fasa demi fasa.

Selain itu, pelaksanaan eKehadiran melalui APDM telah diperkenalkan pada tahun 2013. Pelaksanaan ini dikendalikan oleh seorang pegawai meja dan bukan daripada kalangan guru. Namun begitu, guru kelas juga memainkan peranan dalam mengambil kehadiran murid untuk diberikan kepada pegawai meja tersebut untuk dimasukkan ke dalam sistem APDM dan sekali lagi guru juga perlu mengemas kini rekod kehadiran di dalam buku kehadiran murid. Ini menunjukkan guru kelas terpaksa melaksanakan satu tugas untuk dua sistem.

Dalam pada itu, untuk APDM guru kelas perlu menggunakan internet dan boleh mengemas kini data murid tidak mengira masa dan tempat. Guru penyelaras hanya perlu menyemak data murid menggunakan akaun pentadbir sekolah. Dalam APDM ini pula, Pentadbir sekolah (Administrator APDM)/penyelaras data murid dikehendaki memastikan bilangan murid mengikut Tingkatan dan Kelas adalah betul dan terkini. Ini adalah penting kerana setelah data telah lengkap, urusan mengimport data APDM oleh Sistem Aplikasi Peperiksaan Sekolah (SAPS) dan Sistem Pengurusan Pentaksiran Berasaskan Sekolah (SPPBS) boleh dilakukan untuk memudahkan guru kelas dan guru mata pelajaran mengisi markah peperiksaan dalam SAPS dan mengisi pentaksiran dalam SPPBS. Namun, setelah beberapa bulan sistem Aplikasi Pangkalan Data Murid (APDM) ini diperkenalkan di semua sekolah di Malaysia, masalah yang timbul apabila guru kelas atau penyelaras data murid sekolah tidak mengemas kini data murid yang telah berpindah kerana apabila data murid tidak dibuang dalam APDM, sekolah baharu tidak dapat mendaftar data murid yang baru berpindah kerana berlaku pertindihan data untuk dua sekolah. Lebih-lebih lagi, tahap penerimaan guru terhadap sistem APDM yang baharu diperkenalkan ini juga tidak sama dan sekali gus memberikan impak yang berbeza terhadap output yang dihasilkan. Menurut Yusup Hashim (1998), sesuatu inovasi boleh dikatakan diterima dan dilaksanakan (adoption and diffusion) setelah 84 peratus diterima dan mengamalkan inovasi itu. Penerimaan dan penyebaran inovasi berlaku secara berperingkat. Ada yang dapat diterima dan ada yang memakan masa yang panjang untuk penerimaan. Hal ini di sokong oleh Steve (2001) di mana menurut beliau, guru perlu menyesuaikan diri dengan perubahan jika mereka mahu terus wujud dan dapat mengikut arus dengan kaedah dan teknologi baru. 
Selain itu, aplikasi pangkalan data murid ini mempunyai pautan dengan Jabatan Pendaftaran Negara, SAPS, SPPBS dan Kementerian Pelajaran Malaysia. Sehubungan dengan itu, ketelusan data adalah sangat penting di dalam aplikasi internet ini. Sebagai contoh, jika wujud ralat pada nombor kad pengenalan murid yang telah dimasukkan oleh pihak sekolah, Jabatan Pendaftaran Negara akan mengeluarkan arahan serta merta supaya data tersebut perlu dikemas kini. Namun, masih wujud kelemahan untuk sistem Jabatan Pendaftaran Negara kerana terdapat sebilangan nombor kad pengenalan yang betul tetapi tetap menerima arahan untuk dikemas kini.

Selain itu, terdapat satu sistem yang baharu dikenalkan pada tahun 2015 secara atas talian bagi mengisi markah Pentaksiran Aktiviti Jasmani, Sukan dan Kokurikulum (PAJSK). Guru kelas dan guru mata pelajaran Pendidikan Jasmani dan Kesihatan perlu mengisi pentaksiran bagi setiap murid untuk mendapatkan markah penilaian kokurikulum. Dengan ini, sekali lagi sistem ini juga mempunyai pautan dengan APDM kerana menggunakan pangkalan data yang sama. Sebagai contoh jika guru kelas tidak melengkapkan data murid atau tidak mengemas kini rekod murid, data yang akan keluar dalam sistem PAJSK adalah data yang sama. Masalah akan timbul apabila guru kelas tidak memberi komitmen dengan mengemas kini data murid seperti tarikh lahir murid, sistem PAJSK tidak akan dapat dilaksanakan.

Menurut Fullan (2007), implikasi meluas proses pelaksanaan dan penerusan mengandungi beberapa komponen yang berhubung kait iaitu kunci perubahan melibatkan makna yang berkaitan dengan buah fikiran, program, pembaharuan atau kelompok kegiatan yang baharu. Manakala, Pincus (1974) menyatakan bahawa, tiga faktor yang membantu penerimaan iaitu keselamatan birokrasi, reaksi kepada tekanan luar dan penerimaan oleh rakan sebaya elit.

\section{Objektif Kajian}

a) Mengenal pasti penerimaan pelaksanaan SMM dan APDM dalam pengurusan data murid.

b) Mengenal pasti hubungan di antara pelaksanaan SMM dengan pengurusan data murid.

c) Mengenal pasti hubungan di antara pelaksanaan APDM dengan pengurusan data murid.

\section{Hipotesis Kajian}

$\mathrm{H} \circ 1$ : Tidak terdapat hubungan yang signifikan di antara pelaksanaan SMM dengan pengurusan data murid.

Ho2: Tidak terdapat hubungan yang signifikan di antara pelaksanaan APDM dengan pengurusan data murid.

\section{Tinjauan Literatur}

\section{Model Penerimaan Teknologi}

Beberapa model yang telah dibangunkan dalam menganalisis dan memahami faktor-faktor yang mempengaruhi penerimaan penggunaan teknologi komputer seperti Theory of Reasoned Action (TRA), Theory of Planned Behaviour (TPB), dan Technology Acceptance Model (TAM). 
Terdapat banyak teori yang menjelaskan mengenai penerimaan pengguna terhadap teknologi namun TAM (Technology Acceptance Model) adalah model yang banyak digunakan oleh pengkaji. TAM terbukti secara konsisten dapat menjelaskan faktor yang mempengaruhi penerimaan pengguna teknologi (Vankatesh \& Davis, 2000). Sejak diperkenalkan oleh Davis pada tahun 1989 sampai dengan tahun 2000, terdapat 424 jurnal telah menggunakan teori TAM, dari dua jurnal yang telah diterbitkan oleh Davis (Vankatesh \& Davis, 2000). Dalam kajian ini lebih memfokuskan kepada penerimaan guru terhadap inovasi dalam pengurusan data murid. Ini kerana tidak semua guru dapat menerima perubahan secara berperingkat atau pun sekali gus.

TAM adalah model yang dikembangkan oleh Davis dalam kajiannya mengenai tingkah laku pengguna sistem maklumat. Model ini adalah sama dengan teori penyebaran tetapi lebih menekankan kepada kedudukan psikologi dan pengaruh sosial. Davis menyatakan bahawa hasil yang diinginkan dari penggunaan sistem maklumat tidak akan tercapai jika wujud penghalang dari pengguna sistem itu sendiri (Davis, 1989). Penyebab dari halangan oleh pengguna sistem maklumat, menurut Davis ditentukan oleh dua pemboleh ubah, iaitu keyakinan kemudahan dalam menggunakannya (percieved ease of use) dan keyakinan akan manfaat (percieved usefullness) (Davis, 1989).

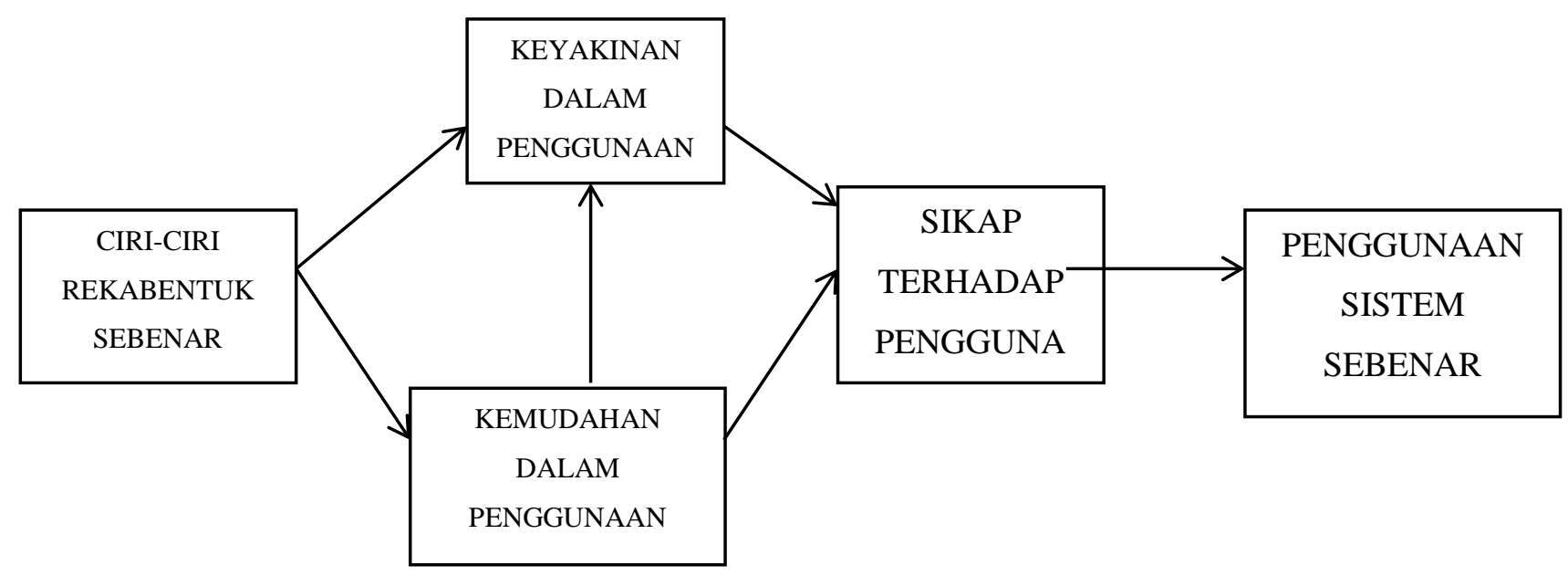

\section{Rajah 3: Model Penerimaan Teknologi (Davis,1989)}

Menurut Davis, kedua - kedua pemboleh ubah ini secara bersama-sama berpengaruh terhadap keinginan menggunakan dan kemudian akan mempengaruhi penggunaan sistem tersebut (Davis, 1989). Dari hasil kajian yang Davis lakukan, terbukti secara signifikan bahawa kedua-kedua pemboleh ubah tersebut memang mempengaruhi keinginan dari pengguna. Hal ini juga disokong oleh beberapa pengkaji yang menggunakan model TAM sebagai rujukannya. Arami, Koller dan Krimmer meneliti penerimaan pengguna kartun mahasiswa elektronik serba guna di Universitas Viena, Austria (Arami, Koller, Krimmer). Model TAM juga digunakan untuk meneliti penerimaan mahasiswa terhadap learning object (Lau, H dan Woods, P, 2007).

Model TAM yang dikemukakan oleh Davis, menurut Kusuma tidaklah terlalu sempurna, dan tidak dapat menjelaskan secara menyeluruh tentang tingkah laku pengguna teknologi. Hal ini disebabkan kerana TAM hanya mempertimbangkan faktor dari sistem atau teknologi itu sendiri (Kusuma, 2008). TAM hanya mampu menjelaskan tingkah laku pengguna dari segi 
manfaat yang dihasilkan oleh teknologi, padahal ada kemungkinan wujud individu yang menggunakan teknologi bukan kerana pada manfaatnya tetapi kerana ada paksaan daripada pihak lain. Paksaan daripada pihak lain ini juga boleh menjadi penghalang kepada pengguna individu walaupun penggunaan teknologi tersebut diyakini manfaatnya.

Dalam pada itu, TAM yang dikembangkan dari teori psikologi, menjelaskan bahawa tingkah laku pengguna komputer adalah berlandaskan pada kepercayaan (belief), sikap (attitude), keinginan (intention), dan hubungan tingkah laku pengguna (user behaviour relationship). Tujuan model ini untuk menjelaskan faktor-faktor utama tingkah laku pengguna terhadap penerimaan pengguna teknologi. Jelas di sini menunjukkan faktor-faktor ini mempunyai hubungan yang kuat dengan pemboleh ubah iaitu SMM dan APDM.

Seterusnya, model ini menempatkan faktor sikap dari tiap-tiap tingkah laku pengguna dengan dua pemboleh ubah iaitu kemudahan penggunaan (ease of use) dan kemanfaatan (usefulness). Kedua pemboleh ubah ini dapat menjelaskan aspek tingkah laku pengguna. Dengan itu, model TAM sebenarnya menjelaskan bahawa persepsi pengguna akan menentukan sikapnya dalam kemanfaatan penggunaan TMK. Model ini secara lebih jelas menggambarkan bahawa penerimaan penggunaan TMK dipengaruhi oleh kemanfaatan (usefulness) dan kemudahan penggunaan (ease of use).

Menurut Kohli dan Kettinger yang tertulis dalam pidato pengukuhan guru besar Hadri Kusuma menyatakan bahawa pemahaman tentang tingkah laku pengguna teknologi harus meliputi pemahaman tentang nilai-nilai peribadi kerana ia memberi motivasi kepada individu untuk menggunakan suatu teknologi, dibandingkan dengan sisi kegunaannya (Kusuma, 2008). Dalam pada itu, Kusuma mengungkapkan bahawa menurut Feather, nilai personal sangat berdekatan dengan motivasi dan sangat baik untuk menjangkakan dan menjelaskan perilaku (Kusuma, 2008). Oleh kerana itu model TAM tanpa variabel personal believes tidak mampu menjelaskan perilaku pengguna secara sempurna. Oleh yang sedemikian, Davis telah mengkaji semula dan menambah satu lagi pemboleh ubah dalam TAM 2 iaitu norma subjektif luaran (Davis \& Vantekesh ,2000). Norma subjektif bermaksud sebagai social belief, iaitu norma sosial dalam masyarakat yang dipercaya oleh individu tertentu.

\section{Reka Bentuk Kajian}

Kajian ini merupakan kajian tinjauan yang menggunakan reka bentuk kajian keratan rentas (Cross Sectional); iaitu pengkaji mengumpulkan data sekali sahaja sepanjang penyelidikan dijalankan. Menurut Tuckman (1978), kaedah ini merupakan satu kaedah yang berkesan bagi mendapatkan maklumat daripada responden; selain daripada membuat pemerhatian terhadap tingkah laku mereka. Soal selidik sebagai instrumen kajian yang melibatkan sampel yang ramai; kajian dengan kos yang sederhana; di samping memberi laluan kepada pensampelan yang tepat (Tuckman 1978 dan Oppenheim 1983 (dalam Tuckman 1978).

Pengkaji menggunakan borang soal selidik yang perlu dijawab oleh guru-guru. Penggunaan soal selidik sebagai instrumen kajian dapat membantu pengkaji memperoleh dan mengumpul maklumat yang banyak serta ia tidak memerlukan masa yang lama untuk menjalankan kajian (Wiersma, 2000).

Kajian ini dibentuk untuk melihat pelaksanaan SMM dan APDM dalam pengurusan data murid di sekolah menengah di mana ia melibatkan penggunaan dan pengetahuan Teknologi Maklumat dan Komunikasi (TMK) guru. Penggunaan dan pengetahuan TMK ini lebih difokuskan untuk menyelesaikan tugas-tugas guru dalam pengurusan data murid. 


\section{Populasi dan Sampel Kajian}

Dalam kajian ini, kumpulan sasaran pengkaji ialah guru kelas di sekolah menengah di Lahad Datu. Populasi kajian ini terdiri daripada mereka yang terlibat secara langsung dalam penggunaan Sistem Maklumat Murid (SMM) dan Aplikasi Pangkalan Data Murid (APDM) dalam melaksanakan pengurusan data murid di sekolah. Sekolah- sekolah yang terlibat ialah SMK Agaseh, SMK Sepagaya, SMK Terusan, SMK Desa Kencana, SMK Silabukan, SMK St Dominic, SMK Segama dan SMK Tungku.

Menurut Mohd Majid Konting (2000), pengenalpastian populasi penting dalam sesuatu penyelidikan kerana pengenalpastian itu menentukan bidang masalah yang perlu dikaji. Populasi guru yang dikaji adalah dari sekolah menengah di Bandar Lahad Datu untuk tujuan penyelidikan.

Pensampelan merupakan strategi penyelidikan di mana penyelidik boleh mendapatkan maklumat tentang sesuatu populasi daripada sebilangan individu yang menganggotai populasi tersebut. Menurut Gay dan Diehl (1992), saiz sampel yang diperlukan ialah 10 peratus daripada jumlah populasi. Walau bagaimanapun bagi populasi yang kecil jumlah sampel yang perlu diambil ialah sebanyak 20 peratus. Ini disebabkan satu generalisasi boleh dibuat daripada hasil kajian yang dijalankan. Walau bagaimanapun, dalam kajian ini semua sampel kajian telah diambil dan digunakan.

Dengan itu jumlah sampel kajian dipilih berdasarkan kepada Jadual Penentuan Saiz Sampel Krejcie dan Morgan (1970) iaitu seramai 181 orang. Namun begitu, pengkaji telah mengedarkan 190 sampel kerana bimbang jika terdapat responden yang gagal mengembalikan soal selidik yang sempurna. Pemilihan guru kelas adalah dibuat kerana mereka lebih banyak terlibat dalam SMM dan APDM khususnya dan penggunaan TMK umumnya. Jumlah sampel keseluruhan dapat dilihat dalam Jadual 1.

Jadual 1: Jumlah Sampel Keseluruhan

\begin{tabular}{lll}
\hline Perkara & Populasi & Sampel \\
\hline Sekolah & 8 & 8 \\
Guru kelas & 346 & 181 \\
\hline
\end{tabular}

Sumber: DATA EMIS Kementerian Pelajaran Malaysia

Di dalam kajian ini, guru kelas yang dipilih menjadi sampel perlu berkhidmat lebih daripada satu tahun di sekolah yang sama supaya mereka dapat mengenal pasti tugas- tugas di sekolah mereka. Pemilihan sampel kajian ini menggunakan kaedah pensampelan rawak mudah. Pensampelan rawak mudah ialah proses memilih sampel yang memastikan semua individu dipilih dari populasi mempunyai peluang atau kebarangkalian dipilih yang sama dan bebas. Pensampelan ialah satu proses memilih sejumlah individu untuk satu kajian daripada satu kumpulan atau populasi yang lebih besar bagi mewakili kumpulan tersebut (Julita Liwan, 2002).

\section{Instrumen Kajian}

Dalam kajian ini, pengkaji menggunakan instrumen soal selidik untuk mengumpul data. Alat kajian ini mengandungi 28 item dan dibahagikan kepada tiga bahagian, iaitu ciri demografi responden, Penggunaan Sistem Maklumat Murid (SMM) Dan Aplikasi Pangkalan Data Murid (APDM) Dalam Pengurusan Data Murid dan Pelaksanaan SMM dan APDM. 


\section{Kerangka Konseptual Kajian}

Kajian ini direka bentuk berdasarkan kerangka konseptual yang ditunjukkan dalam rajah di bawah. Kajian ini mengenal pasti tahap penerimaan guru dari dua sistem pengurusan maklumat yang berbeza iaitu Sistem Maklumat Murid (SMM) dan Aplikasi Pangkalan Data Murid (APDM).

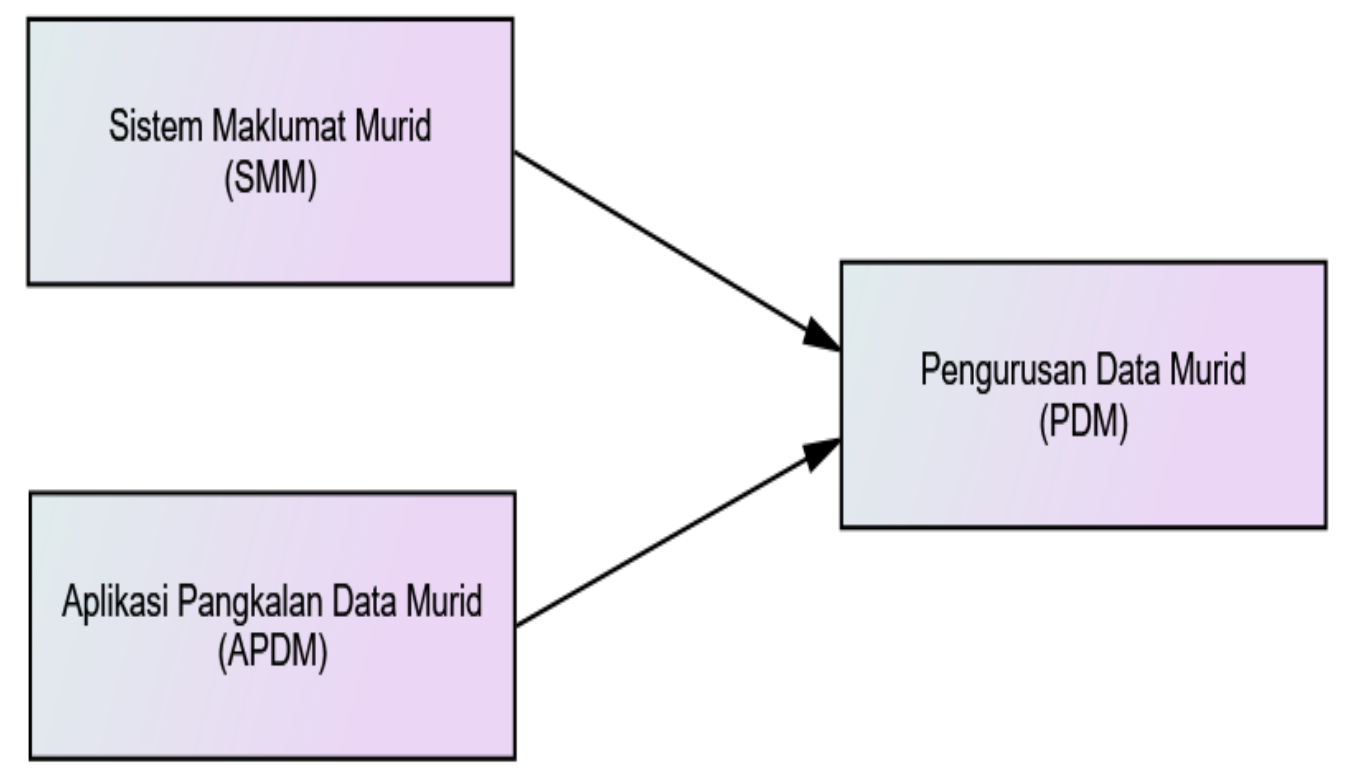

Rajah 4: Kerangka Konseptual Kajian

\section{Dapatan Kajian}

Sejauh Manakah Penerimaan Pelaksanaan Sistem Maklumat Murid (SMM) dan Aplikasi Pangkalan Data Murid (APDM) dalam Pengurusan Data Murid?

Jadual 2: Taburan Kekerapan Penerimaan Guru Terhadap Aplikasi Pangkalan Data Murid (APDM)

\begin{tabular}{llll}
\hline Bil Item & \multicolumn{2}{l}{ Frekuensi } & Peratus \\
\hline 1 Pelaksanaan APDM menambahkan & STS & -2 & 1.1 \\
beban guru yang sedia ada. & TS & -21 & 11.6 \\
& TP & -30 & 16.6 \\
& S & -79 & 43.6 \\
& SS & -49 & 27.1 \\
\hline 2 Berlaku pertindihan kerja dalam & STS & -1 & 0.6 \\
penggunaan SMM dan APDM & TS & -4 & 2.2 \\
kerana kedua-duanya mempunyai & TP & -31 & 17.1 \\
fungsi yang sama. & S & -59 & 32.6 \\
& SS & -86 & 47.5 \\
\hline
\end{tabular}




\begin{tabular}{llllc}
\hline 3 Rakan sekerja saya bersikap positif & STS & -9 & 5.0 \\
dalam melengkapkan data & murid & TS & -22 & 12.2 \\
menggunakan SMM. & & TP & -59 & 32.6 \\
& & S & -70 & 38.7 \\
& & SS & -21 & 11.6 \\
\hline 4 Rakan sekerja saya bersikap positif & STS & -7 & 3.9 \\
dalam melengkapkan data murid & TS & -24 & 13.3 \\
menggunakan APDM. & & TP & -61 & 33.7 \\
& S & -73 & 40.3 \\
& & SS & -16 & 8.8
\end{tabular}

NOTA $=*$ STS $=$ Sangat Tidak Setuju, TS = Tidak Setuju, TP = Tidak Pasti $\mathrm{S}=$ Setuju, SS= Sangat Setuju

Dalam Jadual 2 menunjukkan penerimaan guru kelas terhadap Aplikasi Pangkalan Data Murid (APDM). Merujuk kepada item 1, terdapat 49 orang responden (27.1\%) sangat setuju, 79 orang responden $(43.6 \%)$ setuju, 30 orang responden (16.6\%) tidak pasti, 21 orang responden $(11.6 \%)$ tidak setuju dan 2 orang responden $(1.1 \%)$ sangat tidak setuju bahawa Aplikasi Pangkalan Data Murid (APDM) menambah beban guru yang sedia ada.

Seterusnya, dalam item 2 menunjukkan terdapat 86 orang responden $(47.5 \%)$ sangat setuju, 59 orang responden $(32.6 \%)$ setuju, 31 orang responden $(17.1 \%)$ tidak pasti, 4 orang responden $(2.2 \%)$ tidak setuju dan 1 orang responden $(0.6 \%)$ sangat tidak setuju bahawa berlaku pertindihan kerja dalam penggunaan SMM dan APDM. Manakala, item 3 menunjukkan terdapat 21 orang responden (11.6\%) sangat setuju, 70 orang responden (38.7\%) setuju, 59 orang responden (32.6\%) tidak pasti, 22 orang responden (12.2\%) tidak setuju dan 9 orang responden (5.0\%) sangat tidak setuju bahawa rakan sekerja bersikap positif dalam penerimaan SMM.

Item 4 pula menunjukkan terdapat 16 orang responden $(8.8 \%)$ sangat setuju, 73 orang responden $(40.3 \%)$ setuju, 61 orang responden $(33.7 \%)$ tidak pasti, 24 orang responden (13.3\%) tidak setuju dan 7 orang responden (3.9\%) sangat tidak setuju bahawa rakan sekerja bersikap positif dalam penerimaan APDM.

$\mathrm{H} \circ$ 1: Tidak terdapat hubungan yang signifikan di antara pelaksanaan SMM dengan pengurusan data murid.

Jadual 3: Hasil Ujian Korelasi Pearson Pelaksanaan Sistem Maklumat Murid (SMM) dan Pengurusan Data Murid.

\begin{tabular}{llll}
\hline & & SMM & PENGURUSAN \\
\hline SMM & Korelasi Pearson & 1 & $.345^{* *}$ \\
& Sig. (2-hujung) & & .000 \\
& $\mathrm{~N}$ & 181 & 181 \\
\hline PENGURUSAN & Korelasi Pearson & $.345^{* *}$ & 1 \\
& Sig. (2-hujung) & .000 & \\
& $\mathrm{~N}$ & 181 & 181 \\
\hline
\end{tabular}

** Signifikan pada aras 0.01 (2-hujung).

Jadual 3 menunjukkan hasil analisis perkaitan antara Sistem Maklumat Murid (SMM) dan Pengurusan Data Murid. Didapati nilai p Sig. (2-tailed) adalah $p=0.000$ adalah di bawah 
daripada nilai alpha 0.05. ini menunjukkan terdapat perkaitan yang signifikan antara SMM dan Pengurusan Data Murid.

Walau bagaimanapun dari segi perkaitan, didapati nilai $\mathrm{r}$ adalah bersamaan dengan 0.345 . berdasarkan kepada jadual nilai pekali dan tafsiran kekuatan perkaitan (Davis, 1971 dalam Rusinah Joned dan Sudirman Asmadi, 2003) nilai $r=0.345$ menunjukkan nilai tersebut mempunyai tafsiran kekuatan perkaitan yang lemah atau tidak kuat.

Secara kesimpulannya, hipotesis yang kedua iaitu hipotesis nul tidak terdapat hubungan yang signifikan di antara pelaksanaan SMM dengan Pengurusan Data Murid adalah ditolak.

\section{$\mathrm{H} \circ 2$ Tidak Terdapat Hubungan yang Signifikan di antara Pelaksanaan APDM Dengan Pengurusan Data Murid}

Jadual 4: Hasil Ujian Korelasi Pearson Pelaksanaan Aplikasi Pangkalan Data Murid (APDM) dan Pengurusan Data Murid

PENGURUSAN APDM

\begin{tabular}{llll} 
PENGURUSAN & Korelasi Pearson & 1 & $.383^{* *}$ \\
& Sig. (2-hujung) & & .000 \\
& $\mathrm{~N}$ & 181 & 181 \\
\hline APDM & Korelasi Pearson & $.383^{* *}$ & 1 \\
& Sig. (2-hujung) & .000 & 181 \\
\hline
\end{tabular}

** Signifikan pada aras 0.01 (2-hujung).

Jadual 4 menunjukkan hasil analisis perkaitan antara Aplikasi Pangkalan Data Murid (APDM) dan Pengurusan Data Murid. Didapati nilai p Sig. (2-hujung) adalah $p=0.000$ adalah di bawah daripada nilai alpha 0.05. Ini menunjukkan terdapat perkaitan yang signifikan antara APDM dan Pengurusan Data Murid.

Walau bagaimanapun dari segi perkaitan, didapati nilai $\mathrm{r}$ adalah bersamaan dengan 0.383 . berdasarkan kepada jadual nilai pekali dan tafsiran kekuatan perkaitan (Davis, 1971 dalam Rusinah Joned dan Sudirman Asmadi, 2003) nilai $r=0.383$ menunjukkan nilai tersebut mempunyai tafsiran kekuatan perkaitan yang lemah atau tidak kuat.

Secara kesimpulannya, hipotesis yang kedua iaitu hipotesis nul tidak terdapat hubungan yang signifikan di antara pelaksanaan APDM dengan Pengurusan Data Murid adalah ditolak.

\section{Perbincangan}

\section{Pelaksanaan Aplikasi Pangkalan Data Murid (APDM) dan Pengurusan Data Murid}

Dapatan kajian secara keseluruhannya menunjukkan bahawa terdapat hubungan signifikan di antara pelaksanaan Aplikasi Pangkalan Data Murid (APDM) dan pengurusan data murid tetapi darjah kekuatan adalah lemah. Hasil kajian ini disokong oleh kajian dari luar negara oleh Mira Afrina (2010) mengenai Sistem Maklumat Pelajar (SMP) di Universitas Sriwijaya 
(UNSRI). Beliau menyatakan bahawa SMP ini telah banyak membantu pihak pengurusan dalam merekodkan data pelajar serta menjana laporan yang berkaitan dengan data pelajar.

Walau bagaimanapun, sistem ini juga mempunyai masalah jika pertambahan pelajar berlaku. Ini jelas menunjukkan bahawa sistem ini mempunyai hubungan dengan pengurusan data pelajar namun masih wujud masalah dan cabaran dalam melaksanakannya. Ini menyamai dengan hasil dapatan pengkaji dalam menganalisis hubungan di antara APDM dan pengurusan data murid.

Dalam dapatan ini juga menunjukkan bahawa APDM adalah inovasi yang diketengahkan oleh kementerian yang memainkan peranan yang penting dalam pengurusan data murid. Menurut Altrichter Herbert (2006), elemen yang perlu difokuskan dalam pelaksanaan inovasi ialah praktis, material, instrument dan ruang. Dalam konteks pengkaji, dalam melancarkan pelaksanaan APDM ini pihak pentadbir perlu menyediakan taklimat yang cukup, material yang selesa dan ruang yang kondusif. Sebagai contoh, setiap sekolah perlu menyediakan ruang yang berhawa dingin sesuai dengan keadaan perkakasan komputer dan capaian internet yang baik.

\section{Sistem Maklumat Murid (SMM) dan Aplikasi Pangkalan Data Murid (APDM)}

Dapatan kajian secara keseluruhannya menunjukkan bahawa terdapat hubungan signifikan di antara pelaksanaan Sistem Maklumat Murid (SMM) dan Aplikasi Pangkalan Data Murid (APDM) dan darjah kekuatan ialah kuat. Ini adalah disebabkan oleh kedua-dua sistem ini saling bergantung kerana mempunyai fungsi yang sama.

APDM adalah inovasi yang diperkenalkan oleh kementerian bagi tujuan memudahkan dan melicinkan proses pengurusan data sekolah. Ia disokong dalam kajian Rahmad (2005) menyatakan bahawa perkembangan Teknologi Maklumat dan Komunikasi (TMK) dalam pengurusan adalah lebih cepat berbanding dengan proses pengajaran dan pembelajaran. Ini kerana pengenalan TMK dalam pengurusan organisasi pendidikan adalah bermula sejak 1970-an lagu (Mener, 2002).

Pelaksanaan Aplikasi Pangkalan Data Murid (APDM) ini memerlukan komputer dan internet dalam pengurusan data murid seharian. Ini selari dengan kajian yang dijalankan oleh Rowen (2000) menyatakan bahawa di Amerika Syarikat didapati 40\% daripada guru yang sering menggunakan komputer dan internet di sekolah untuk tujuan merekodkan hal-hal pengurusan sekolah.

\section{Kesimpulan dan Cadangan}

Berdasarkan kepada dapatan analisis kajian yang telah dibincangkan, beberapa cadangan dikemukakan dengan harapan dapat menyumbang ke arah pengurusan data murid yang lebih efisien dengan menggunakan inovasi yang telah diperkenalkan. Antara cadangan tersebut termasuk:

\section{Penglibatan Pihak Pentadbiran}

Kajian tentang pemimpin dengan pelaksanaan inovasi sekolah dan menunjukkan peranan pemimpin adalah sangat penting. Namun adalah dicadangkan supaya pemimpin sekolah berbincang dengan penolong kanan dan guru kelas untuk membuat keputusan kaedah yang paling sesuai untuk melicinkan pengurusan data murid yang perlu sentiasa dalam keadaan kemas kini. 
Sehubungan dengan itu, pihak pentadbiran perlu sentiasa membuat tinjauan ke atas guru kelas dalam pengurusan data murid. Tinjauan guru adalah penting kerana guru kelas merupakan individu yang paling dekat dengan teknologi (Mener, 2002). Selain itu, tinjauan daripada pihak pentadbir adalah perlu bagi memastikan guru kelas sentiasa mengemas kini data murid di pangkalan data.

\section{Mengubah Sikap Guru dan Program Perkembangan Staf}

Dalam usaha untuk meningkatkan pengintegrasian Teknologi Maklumat dan Komunikasi (TMK) di sekolah, faktor yang tidak kurang pentingnya ialah dengan mengubah sikap guru yang takut dan fobia menggunakan komputer. Langkah yang dikenal pasti ialah dengan mendedahkan guru kepada kursus-kursus yang berkaitan dengan TMK.

Dalam pada itu, guru-guru juga perlu diberikan taklimat yang cukup mengenai penggunaan Sistem Maklumat Murid (SMM) dan Aplikasi Pangkalan Data Murid (APDM) dalam pengurusan data murid. Sebagai contoh, Aplikasi Pangkalan Data Murid (APDM) adalah satu sistem yang baharu diperkenalkan dan memerlukan penerangan yang jelas daripada pihak yang bertanggungjawab.

Selain itu, sistem ini perlu mempunyai kualiti yang setanding atau lebih dari sistem yang sebelumnya untuk meningkatkan tahap penerimaan guru-guru. Baker (1991) menyatakan bahawa beberapa halangan yang telah dikenal pasti dalam melaksanakan perubahan sistem iaitu guru (pelaksana), kurang kemahiran dan pengetahuan, kekurangan kemudahan, keyakinan diri dan komitmen terhadap tugas yang diberi.

Selain itu faktor yang turut mempengaruhi sikap dan tahap kesediaan guru menggunakan TMK ialah efikasi kendiri menggunakan TMK. Kajian Ropp (1999) mendapati guru-guru pelatih yang yakin dengan kebolehan mereka untuk melakukan tugasan komputer juga mempunyai sikap yang lebih positif terhadap penggunaan teknologi. Kajian oleh Hirschbuhl dan Faseyitan (1994) serta Ertmer et. al (1994) juga mendapati efikasi kendiri mempengaruhi tahap kesediaan guru menggunakan TMK. Ini bermakna guru-guru yang mempunyai efikasi kendiri yang tinggi akan lebih kerap menggunakan TMK kerana mereka yakin dan percaya kepada kebolehan mereka untuk menggunakan TMK dalam proses pengajaran dan pembelajaran di bilik darjah.

Manakala guru-guru yang kurang yakin dengan kebolehan mereka menggunakan TMK (efikasi kendiri menggunakan komputer rendah) akan teragak-agak dan tidak yakin dengan kebolehan mereka untuk menggunakan TMK di sekolah (Ropp 1999). Oleh itu, dalam usaha untuk meningkatkan efikasi kendiri positif guru, sewajarnya golongan pendidik ini diberi pendedahan untuk meningkatkan pengintegrasian TMK di bilik darjah melalui kursus-kursus TMK yang lebih intensif.

\section{Meningkatkan Penyelarasan Perkakasan dan Perisian TMK di Sekolah}

Setiap sekolah telah dibekalkan dengan perkakasan dan perisian TMK, namun penyelenggaraan peralatan dan perisian ini tidak dilaksanakan. Kebanyakan perkakasan dan perisian komputer di sekolah tidak mempunyai kualiti yang baik dan bukan yang terkini dalam pasaran. 
Justeru, penyelarasan ini perlu dilakukan dari semasa ke semasa dan secara berterusan (Jantzie, 2002). Glennan dan Melmed dalam Mener (2002) menyatakan sebuah sekolah yang maju dengan teknologi dan berjaya mengimplementasikan teknologi dengan berjaya apabila terdapat seorang penyelaras teknologi sepenuh masa. Oleh yang demikian, adalah dicadangkan supaya seorang penyelaras teknologi yang bukan dari kalangan guru sekolah boleh dilantik untuk mengawal segala implementasi sistem di sekolah. Penyelaras teknologi ini juga boleh memberi garis panduan dan nasihat yang bersesuaian kepada pentadbir sekolah supaya pelaksanaan inovasi ini boleh dilaksanakan dengan berjaya.

\section{Penutup}

Beberapa pertimbangan dan cadangan telah dikemukakan yang mungkin akan dapat membantu pihak-pihak yang berkaitan dalam bidang pengurusan data murid mengikut keperluan negara dan dunia semasa. Ini adalah untuk memastikan supaya bidang pendidikan di Malaysia sentiasa berkembang dari pelbagai sudut berasaskan Teknologi Maklumat dan Komunikasi (TMK). Secara keseluruhannya, kajian ini mendapati pelaksanaan inovasi TMK mempunyai hubungan yang positif dalam pengurusan data murid di daerah Lahad Datu. Penerimaan guru juga dilihat menjadi faktor penggalak kepada kementerian dalam memperkenalkan lagi sistem yang mempermudah dan mempercepatkan pengurusan data murid. Konklusinya, perlu disedari bahawa TMK yang berlaku tanpa mengira masa dan lokasi. Semua guru perlu sentiasa mengambil inisiatif untuk mempertingkatkan kemahiran TMK supaya tidak tenggelam dalam arus perubahan yang begitu pantas.

\section{Rujukan}

Abdull Sukor Shaari, Abdul Rahim Romle \& Mohammad Yazi Kerya. 2006. Beban Tugas Guru Sekolah Rendah. Seminar Kebangsaan Kepimpinan dan Pengurusan Sekolah 12-14 Februari 2006, Alson Klana Resort, Seremban.

Ahmad Taufiq Azlan. 2010. Sistem Maklumat Disiplin Pelajar. Tesis Sarjana. Universiti Teknologi Malaysia.

Alias Baba. 1999. Statistik penyelidikan dalam pendidikan dan sains sosial. Bangi: Penerbit Universiti Kebangsaan Malaysia.

Ardi Hamzah. 2009. Evaluasi Kesesuaian Model Keperilakuan Dalam Penggunaan Teknologi Sistem Informasi Di Indonesia. Seminar Nasional Aplikasi Teknologi Informasi(SNATI 2009)

Azizi Yahaya dan rakan-rakan. 2007. Menguasai penyelidikan dalam pendidikan. PTS professional publishing SDN. BHD.

Arsaythamby Veloo \& Arumugam Raman (2009). Panduan Menganalisis dan Mengintegrasi Data. Penerbit Universiti Utara Malaysia.

Azwan \& Rozita. 2002. Literasi Komputer Maklumat dan Komunikasi (TMK) guru-guru sekolah Menengah: Satu kajian berbentuk "hand on". Prosiding Konvensyen Teknologi Pendidikan ke 17, Paradise Sandy Beach Resort, Tanjung Bungah, Pulau Pinang, pp 206-216.

Chua Yan Piaw. 2012. Asas Statistik Penyelidikan. McGraw-Hill (Malaysia) SDN. BHD.

Dewan Bahasa dan Pustaka. 1999. Kamus Dewan. Kuala Lumpur: Dewan Bahasa \& Pustaka.

Fullan, M. 2007. The New Meaning of Educational Change. Teachers College, Columbia University.

Fullan, M. 2006. Turnaround Leadership. Jossey-Bass A Willey Imprint, San Francisco.

Fullan, M. 2006. Accomplishing District-Wide Reform. Journal of School Leadership.

Fullan M. 1999. Technology and the Problem of Change. Ontorio Institute for Studies in Education University of Toronto. 
Ghitulescu, b E. 2013. Making change happen: The impact of work context on adaptive and proactive behaviours. Journal of Applied Behavioral Science 49(2): 206-245

Glennan, T. K., \& Melmed, A. (1995). Fostering the use of educational technology: Elements of a national strategy. Retrieved January 15, 2002.

Hargreaves, A. and Fullan M. 1992. Teacher Development and Educational Change. Burgess Science Press, Basingstoke.

Jantzie, G. N. (2002). New technologies and the struggle for the classroom: Investigating the attitudes of teachers and a teachers' professional organization toward the implementation of new communications and information technologies. University of Calgary.

Julita Liwan. 2002. Peranan guru mata pelajaran dan masalah dalam pelaksanaan pengurusan kurikulum di sekolah. Kertas Tesis Sarjana. Universiti Kebangsaan Malaysia.

Melvina Chung Hui Ching \& Jamaludin Badusah. 2010. Sikap Guru Bahasa Melayu terhadap Penggunaan Teknologi Maklumat dan Komunikasi (ICT) dalam Pengajaran di Sekolah-sekolah Rendah di Bintulu Sarawak. Jurnal Pendidikan Malaysia 35(1) (2010): 59-65.

Mira Afrina. 2007. Sistem Maklumat Pelajar Universitas Sriwijaya (Unsri) Palembang Indonesia. Tesis Sarjana. Universiti Teknologi Malaysia.

Mohd Majid K. 2000. Kaedah Penyelidikan Pendidikan. Kuala Lumpur; Dewan Bahasa dan Pustaka.

Mohd. Nihra Haruzuan Mohamad Said dan Intan Marini Suhaimin. 2008. Pembangunan Sistem Pengurusan Maklumat Pelajar. Jurnal Pendidikan Malaysia 26(2) (2008): 1119.

Mok Soon Sang. 2008. Pengurusan Hal Ehwal Pelajar. CIPTA Printing \& Publishing (M) SDN BHD.

Mok Soon Sang. 2012. Prinsip dan Teori Penolong Kanan Pentadbiran Sekolah. Penerbitan Multimedia SDN. BHD.

Norasiah Abdullah, Rosnah Ahmad Zain, Mazilah Abdullah. 2011. Teknologi Maklumat dan Komunikasi. Penerbitan Multimedia Sdn. Bhd.

Pajares M. Frank. 1992. Teacher's belief and Educational Research. Cleaning Up A Messy Construct. Educational Research, Fall 1992, Vol.62, No.3, pp. 307-332.

Park, J.h. \& Jeung, D.W. 2013. School reforms, principal leadership and teacher resistence: Evidence from Korea. Asia Pacific Journal of Education 33(1): 34-53.

Peter N. 2005. Context Based Learning of Science. Waxmann Publishing Co.

Rahmad Sukor. 2005. Inovasi IT dalam Pengurusan Pendidikan, Sufean Hussin Shahril @ Charil Marzuki dan rakan-rakannya (ed). Pentadbiran dalam Pembangunan Pendidikan. KualaLumpur : PTS Professional Publishing SDN BHD.

Rowen. C. 2000. Teacher Use of Computer and The Internet in Public Schools. Stats in Brief, Washington, D.C, National Center for Educational Statistic.

Tuckman. 1978. Conducting educational research. 2nd. Edition. Boston: Hercant B. J. Inc.

Wiersma, W. 2000. Research methods in education an introduction. Boston: Allyn and Bacon Publisher.

Zamri Abu Bakar dan Rusmini Ku Ahmad. 2007. Implementasi ICT dan Kepimpinan Sekolah: Kajian Kes di Sekolah-Sekolah Bestari dan SMKJKC.

Zawiyah Mohammad Yusof Dan Mariah Lambak. 2008. Pengurusan Sistem Maklumat Pendidikan: Implikasi Pengautomasian ke Atas Pengajaran dan Kebolehgunaan Data. Akademika 74 (Disember) $2008: 89$ - 113 